\title{
Hostages, free lunches and institutional gaps: the case of the European Currency Union
}

\author{
Günter Franke
}

\begin{abstract}
This paper argues that the strong member states of the European Currency Union are hostages of a financiall distressed member state so that they are compelled to provide financia support. Moreover, due to the dynamics of the interaction game, a debt relief is a free lunch for the distressed country. This fosters moral hazard of distressed countries. In the absence of capital market control, European politics do not effectively monitor fisca politics of member states. The lack of a long-term strategy of the European Currency Union to deal with distressed states has undermined the credibility of politics. This lack is also explained by a lack of a European Insolvency Charter. A viable Union requires such a charter with rules for handling distress. Moreover, politics should determine a mechanism to coordinate politics and capital markets in their monitoring of fisca and economic policy of member states.
\end{abstract}

Keywords European Currency Union - European Insolvency Charter · Hostages · Free lunch · Externalization hypothesis

JEL Classificatio $\mathrm{E} 62 \cdot \mathrm{F} 36 \cdot \mathrm{F} 53 \cdot \mathrm{H} 30 \cdot \mathrm{H} 60$

\section{Introduction}

The financia crisis, which started in the banking industry in 2007 , led to an intense discussion about bank regulation. Three years later, the next crisis emerged in the European Currency Union (ECU). It is driven by financia distress of some member states and aggravated by erratic politics of the ECU towards those states. The ECU started to seriously address distress issues only after capital markets sent alarm signals. The Lisbon Treaty provides little guidance for the ECU how to deal with financia distress. These observations indicate the need to improve the institutional

\section{G. Franke ( $\bowtie)$}

University of Konstanz, Konstanz, Germany

e-mail: guenter.franke@uni-konstanz.de 
framework of the ECU. Moreover, politics should acknowledge the need for capital market signals and assign a role to capital markets which they should play in the monitoring of member states.

The importance of the legal system for the economic functioning of a country is well known and documented in various empirical papers. A well designed and enforced legal system supports efficien y because it reduces uncertainty about the existence of claims, about their legal contents and about their enforceability. In addition, it reduces asymmetric information between economic agents and, thereby, mitigates problems of adverse selection and moral hazard. Thus, it mitigates market imperfections. Coordination and other costs in transactions between economic agents are reduced.

A related coordination problem arises in international firms Williamson (1975, 1985) asked whether a fir should use the market mechanism to coordinate its activities in different countries or rely on its internal coordination through its own office in these countries. The markets-versus-hierarchies discussion motivated Williamson's internalization hypothesis. It states that coordination in hierarchies is more preferable to coordination through markets, the stronger market imperfections are. The underlying assumption is that market imperfections imply various costs of market transactions while the decision maker in a hierarchy, who is well informed about the hierarchy, acts in the interest of the principals and enforces his decisions within the hierarchy at low cost.

Coordination problems, although of a very different nature, arise among member states of a currency union such as the ECU. The members of such a union are largely independent states which have given up their own currencies in favour of a joint currency. Stability of the joint currency can be assured if the economies of the member states are similar in competitiveness, economic growth and fisca policies. Otherwise imbalances between these countries tend to build up, create tensions in the currency area and, in the end, endanger the currency union (Mundell 1961). In case of strong imbalances: what are the appropriate answers to mitigate them? Should each member state itself combat its imbalance, should the member states together combat or should imbalances be "socialized" through monetary transfers between member states? In any case, strong imbalances of some member states create (negative) external effects on the other member states which destabilize the currency union. To avoid that, coordination among the member states is required.

Coordination may be achieved by hierarchies within the currency union. However, in a currency union there is no central decision maker who issues and enforces guidelines for all member states. Central authorities in a currency union often have little power so that internalization based on a strong head of the hierarchy is not applicable. This is true in particular if the legal agreement on governance among member states is fragmentary, i.e. legal arrangements for coordination leave much discretion to member states, even in financia distress. Given a lack of rules, coordination can only be achieved through mutual consent of the governments of member states. In the presence of conflict of interest, such coordination is doomed to be ineffective, leading to serious imperfections in internal coordination. This provides room for "externalization", i.e. a strong role for capital markets in monitoring member states. If 
states financ their budget deficit by issuing bonds instead of printing money, ${ }^{1}$ capital market signals indicate the terms at which investors are ready to provide fresh money. These terms have a strong impact on future budgets of distressed states and, thus, on their solvency. What should then be the roles of hierarchy and of capital markets in coordinating states within a currency union? The "externalization hypothesis" claims: The weaker the political coordination between the member states, the more important is the monitoring of capital markets. In other words, the stronger are the imperfections of internal political coordination, the stronger is the desirable "external" coordination role of capital markets.

I use the recent history of the interaction between the ECU and Greece as a case study. First, I argue that the strong member states of the ECU are hostages of the financiall distressed member states, i.e. the strong states have to provide financia support to the distressed states in order to preserve the ECU. Second, in the sequential game between the ECU and Greece, a debt relief for Greece is a free lunch which motivates moral hazard. Third, political monitoring in the ECU has been ineffective. The ECU started to address the Greek problem seriously only after capital markets sent strong signals of Greek insolvency. Fourth, I argue that the lack of an appropriate legal framework for dealing with financia distress of member states explains part of the coordination problems and of the turbulences within the ECU. This lack supports moral hazard of politics in member states and renders restructuring of weak states difficult These observations provide strong arguments for a European Insolvency Charter. Such a charter should constrain politics of the ECU in the case of distress and, thus, make politics more predictable. It should also provide information about the effects of insolvency on a distressed member state and thereby constrain moral hazard of its politics.

This paper addresses problems in the ECU. Although there is a strong connection between the European Union (EU) and the ECU, I focus on the ECU as far as possible. The paper does not address the question whether a distressed country should leave the ECU and return to its own national currency. This issue raises complex questions that cannot be discussed here.

The paper is structured as follows. Section 2 sketches the rules for fisca prudence in the ECU, Sect. 3 the recent history of the ECU. In Sect. 4 I try to improve our understanding of the observed interaction between the ECU and a distressed member state together with long-run implications of current ECU-politics. The "externalization hypothesis" will also be set forth. Some basic considerations about a European Insolvency Charter are offered in Sect. 5. Section 6 concludes.

\section{Rules for fisca prudence in the ECU}

The problems of coordinating member states of the ECU are partly driven by the rules for fisca prudence. Therefore these rules will be sketched first When the idea of a currency union emerged at the beginning of the nineties in the last century, strong

\footnotetext{
${ }^{1}$ The European Central Bank may financ current account deficit through the Target 2 system. But it is not allowed to provide money to a government or other public authorities to fund budget deficit (see Sect. 2).
} 
differences among the European economies obviously existed. Some countries faced rather low inflatio rates while others faced much higher ones. Therefore, in the European Currency System which preceded the ECU and was established in 1979, some currencies were devalued against the DM at more or less regular time intervals. The exchange rates were pegged, but governments could adjust them when necessary. This adjustment permitted to restore international competitiveness of member states. Also, different yields to maturity of government bonds reflecte differences in national inflatio rates and credit quality. Yields to maturity, adjusted to national infla tion rates, also differed substantially. The rather high yields imposed by investors on some states provided a natural brake to excessive borrowing and, thus, to high budget deficits The capital market acted as a forceful monitor of government policies. ${ }^{2}$

Before the start of the ECU the question emerged which instruments might substitute for exchange-rate fl xibility which would be lost in a currency union. In view of strong economic heterogeneity between member states, the answer was eventually provided by the Maastricht criteria combined with a no-bailout clause. Surprisingly, the Maastricht criteria constrained governments in few aspects of heterogeneity only. To apply for membership in the ECU, the sovereign debt of a country must not be higher than 60 per cent of its GDP and the annual increase in debt must not be higher than 3 per cent of GDP. In addition, the inflatio rate must not exceed that of the three most stable countries by more than 1.5 per cent, the yield to maturity of long-term government bonds must not exceed that of the three most stable countries by more than 2 per cent and the country must have been a member of the European Currency System for at least two years with no devaluation of its currency. Thus, a country was allowed to join the ECU if it satisfie certain financia criteria.

Once a country has joined the ECU, then only restrictions on sovereign debt apply. The Maastricht Treaty established procedures for countries which violate the two criteria on indebtedness. Of primary importance is the 3 per cent criterion. If new debt is likely to exceed 3 per cent of GDP, then the European Commission issues an early warning. If it actually exceeds 3 per cent, then the Commission starts a defici procedure. In a firs step, the country has to present a plan how to cut back the deficit If it does not live up to this plan, then the ECOFIN (= council of financ ministers) can impose financia sanctions, such as a penalty of between 0.2 to 0.5 per cent of GDP or a deposit with the ECU which earns no interest and can be withdrawn only after correction of the excess deficit The restrictions on indebtedness may be ignored in case of a crisis, define by a drop in GDP of at least 0.75 per cent.

A major problem is that the European monitoring mechanism focuses exclusively on sovereign indebtedness. Other warning signals are mostly ignored. Restrictions on inflation wage increases, international competitiveness, etc. were never introduced. Perhaps many politicians hoped that convergence between national economies would be enforced by the market mechanism and by European directives which then would homogenize laws of the member states. This setting gives national politics a wide range of discretion. For instance, wage and price increases can be much higher in one state relative to the others. Or a state may run a strong currency account deficit

\footnotetext{
${ }^{2}$ This may also explain why some East-European member states of the EU which, however, do not belong to the ECU, and many developing countries have rather low public debt.
} 
Moreover, monitoring by capital markets is never mentioned in the Maastricht Treaty. Thus, if a state has a bad debt rating, no political action needs to be taken. It is implicitly assumed that once indebtedness satisfie the Maastricht criteria, the state can issue bonds to financ itself.

If a state runs into liquidity problems, Art.104 rules out that national central banks or the ECB provide direct credit to public authorities, define in a comprehensive sense. This article does not rule out, however, purchases of government bonds in secondary markets by the ECB. Art.104 b states that the Community shall not be liable for commitments of member states. This article is interpreted as a no-bailout clause. Regarding the sanctions in case of violation of the debt criteria, the implicit assumption of the Maastricht Treaty appears to be that the sanctions are sufficien to force states back on a trajectory satisfying the Maastricht criteria. This may explain the absence of rules for the case that a state does not get back on track.

The Lisbon Treaty emanated from the Maastricht Treaty. The rules regarding fis cal discipline are similar. Details of how the ECU has to proceed in the supervision of member states are codifie in Art.126 of the Treaty on the Functioning of the European Union (TFEU). The no-bailout clause is now codifie in Art. 125. Art. 122, however, provides an exception to this clause. When a member state is in difficultie or is seriously threatened by natural disasters or exceptional occurrences beyond its control, on a proposal from the Commission, the Council (= the heads of the national governments of the ECU-states) may grant financia assistance to the member state under certain conditions, ${ }^{3}$ This clause provides room for political discretion in a crisis.

Figure 1 depicts potential trajectories of ECU-member states together with the presence/absence of rules for the ECU how to proceed. When a state enters the ECU, it is supposed to be liquid and solvent. In the next stage, the state may run into liquidity problems, ahead of solvency problems. Then the Treaty allows the European Union to grant financia support under certain conditions. But if the state runs into solvency problems, then there are no rules how to proceed. State insolvency is unchartered territory.

\section{What happened in the firs decade of the ECU? The Greek case}

Due to the introduction of the Euro and the European Central Bank (ECB) policy, inflatio rates which had been high in some countries in the nineties, came down substantially even though they clearly continued to differ among the ECU-member states. Interest rates at which member states issued government bonds also strongly converged. The associated decline in borrowing rates motivated some states to increase their borrowing substantially. When GDP also increased in these states, their borrowing was not considered a serious problem. Instead, GDP-growth in countries like Greece was welcome because it was interpreted as a sign of convergence between member states. There was little discussion whether the GDP-growth in some country

\footnotetext{
${ }^{3}$ Art. 143 also allows the EU to support member states in case of current account imbalances and associated foreign exchange reserve problems. But this applies to member states which are not members of the ECU.
} 
Fig. 1 Potential trajectories of Date Member States

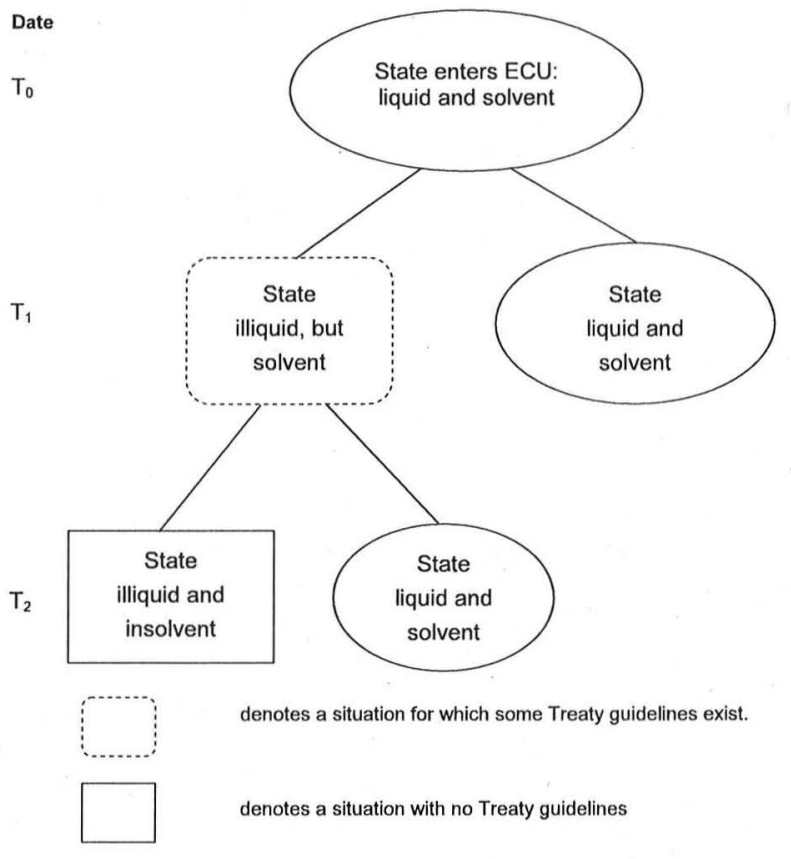

was caused by an improvement of international competitiveness or by an increase in consumption finance by borrowing.

Germany and France were the firs larger member states to violate the 3 per cent rule in 2002 when they faced problems of an economic downturn. Even though this violation was intensively discussed in the ECU, no sanctions were taken. This paved the way for other states to violate the Maastricht criteria without facing serious sanctions. The financia crisis which started in 2007 led to a violation of the 3 per cent rule in many states driven by lower tax revenues and by Keynesian politics to combat the crisis. This crisis was considered an exceptional situation in which the Maastricht criteria should not apply. Instead, defici spending was encouraged to mitigate the crisis effects. Therefore, in 2008 and 2009 fisca deficit grew in many member states.

The financia crisis hit many banks which had bought structured financ products like mortgage-backed securities most of which were issued in the US. Banks in Ireland incurred heavy losses due to these transactions, in contrast to banks in Greece, Italy and Spain. Savings banks in Spain, however, were caught by their excessive lending to real estate investments. These were stimulated by the drop in real interest rates in Spain due to the introduction of the Euro. The housing construction boom fostered Spanish GDP-growth and lowered unemployment, both of which were welcome. But the real estate investments turned out to be a disaster since most of the new houses could not be sold. The mortgages, important loan collateral for banks, lost most of their value.

The deterioration in the financia situation of most member states was largely ignored by politicians because it was attributed to the financia crisis. It took until December 2009 when Standard \& Poor's questioned the quality of Greek government debt. Greece violated the 3 per cent rule in each year from 2000 on. Yet, it attracted 


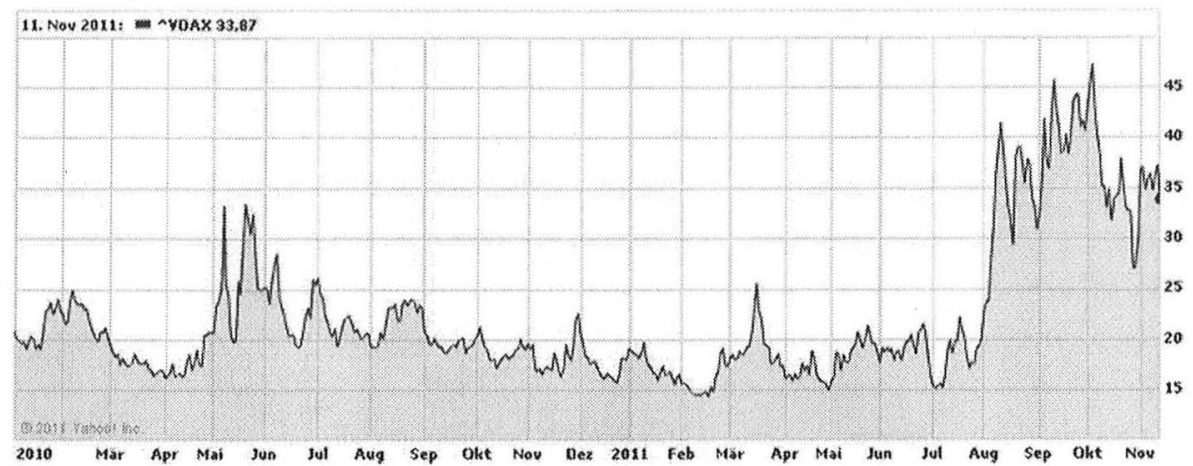

Fig. 2 VDAX. The VDAX measures the implicit volatility of the DAX over the next 45 days

little attention presumably because it is a small country. 10-year-yields of Greek government bonds exceeded those of German government bonds by 20 to 30 basis points in the years 2002 to 2007 . From March 2003 to December 2007 the premium for credit default swaps on government bonds was on average 4 basis points for Germany and 11 basis points for Greece (Bindseil and Modery 2011, p. 219). Presumably investors did not believe the no-bailout clause. In 2008 the yield difference started to increase. Credit spreads for Greece jumped up dramatically after December 2009. In 2010 , the spread started at 2.82 per cent. In the week before the meeting of the Council in Brussels on May 8/9, 2010, it jumped to 9.65 per cent which represents an increase of about 1/3 within one week (Bindseil and Modery 2011, Table 3).

The Greek problem was interpreted by the Council as a liquidity crisis so that the ECU and the IMF agreed on a financia support package on May 8, 2010. The support package amounted to 80 bio $€$ from the ECU and 30 bio $€$ from the IMF. This support is conditioned on an austerity program imposed on Greece. The full amount can only be paid out in tranches upon the fulfilmen of sequential milestones by Greece (European Commission 2010). Whether Greece has fulfille a milestone, is decided upon by a troika of the ECU, the ECB and the IMF.

The support package was interpreted as a temporary liquidity support, consistent with the no-bailout clause. No creditor was asked for a haircut or a moratorium. Capital markets calmed down after the announcement of the support package. The ECB had already purchased government bonds of Greece and other "infected" states and still accepted Greek government bonds at face value as collateral. The effect of these measures was to lower Greek credit spreads and government bond yields in the week after May 9, 2010.

Several tranches were paid out to Greece in 2010. In 2011 the scepticism about Greece increased since the milestones in the agreed austerity program were not satisfied High discounts for Greek government bonds in secondary markets indicated that investors did not believe in the capacity of Greece to avoid a default. Thus, markets considered Greece insolvent, not only illiquid. Uncertainty as perceived by capital markets grew strongly in March 2011 as evidenced by the spread on credit default swaps for Greece and by the VDAX. The VDAX measures the implicit volatility of the DAX (Fig. 2). Both market indicators came down when politicians acknowledged the insolvency of Greece and promised to take action. 
In May 2011, the ECU and the IMF revised their May 2010 support package. $^{4}$ Again, they faced the problem to support Greece and to prohibit unpredictable capital market reactions which might be triggered by a disorderly default of Greece, similar to those triggered by the Lehman default. Thus, a disorderly default of Greece had to be avoided. The ECB refused to take a loss on the large volume of Greek government bonds it had bought in secondary markets. Also the IMF which never suffered a loss from its lending refused a loss on its claims against Greece. As a consequence, politicians started a campaign asking banks and insurance companies which held Greek government debt to agree "voluntarily" to a haircut of 21 per cent. This haircut is "voluntary" because it does not become effective without the consent of banks and insurance companies. But there is strong political pressure on financia intermediaries from governments to accept this haircut.

A "voluntary" haircut of a given size, called a "selective default", offered several advantages over a disorderly default. Banks could check in advance whether their equity capital would be sufficien to bear the loss. Thus, one might expect that banks with insufficien capital would deny the haircut or raise their equity capital and thereby stabilize the banking system. The credit spread for Greece and the VDAX actually came down after the May-Council meeting. Moreover, this "voluntary" haircut did not lead to an officia default rating. Greece was rated CCC instead of D. ${ }^{5}$ In July 2011, after most banks had agreed to the haircut and the Council had indicated to help Greece, the VDAX declined once more. But it went up strongly in August when it became apparent that Greece could not match the milestones of the austerity program. In October 2011, the Greek situation deteriorated once more. The troika firs refused to issue the compliance statement necessary for the payout of the next tranche. A few days later, the troika announced that the Greek situation was worse than expected, but it nevertheless recommended the payout of the next tranche, combined with a stronger haircut to avoid a disorderly default.

At the end of October 2011 the Council asked banks and insurance companies for a higher haircut of 50 per cent. The financia intermediaries "voluntarily" agreed again. Presumably they will be offered to exchange their Greek bonds for new bonds with half the par value. The new bonds will probably be partly guaranteed by the European Financial Stability Fund (EFSF) such that the EFSF will take a First Loss Position of 20 to 30 per cent. Moreover, beyond the financia support of 109 bio $€$ agreed upon in May 2010, an additional support facility of 100 bio $€$ was agreed upon in October 2011. This demonstrates the strong efforts of the ECU to avoid a disorderly Greek default.

Since the high haircut might endanger banks, the Council also insisted on a recapitalization of banks. The banks have to assure a core tier-1 ratio of 9 per cent by the end of June 2012. For that purpose they may attract private money, or, if that turns out to be impossible, they would have to take public money from their government or

\footnotetext{
${ }^{4}$ The ECU raised the EFSF-volume to 440 bio and added 60 bio $€$ from the European Financial Stabilization Mechanism while the IMF promised to back a 250 bio $€$ loan. In order to financiall support distressed member states, the EFSF can also provide partial guarantees for newly issued bonds of the member states. This leveraging allows the EFSF to support bonds with a par value of more than 1 bio $€$.

${ }^{5}$ This led to the strange implication that credit default swaps on Greece did not pay any damage claims even though bondholders suffered substantial losses.
} 
from the EFSF. Even though the haircut reduces Greek public debt by about 100 bio $€$, the major problem will be to restore competitiveness of the Greek economy. To foster that, the Council insisted that the troika should stay in Greece permanently to monitor progress. At the same time, another ECU-team is also permanently working in Athens to develop promising perspectives for Greek recovery.

In order to enforce more fisca and economic prudence within all member states of the ECU, a new "economic government" is established in Brussels which will discuss the economic situation in the member states on a monthly basis. In addition, the Council shall meet twice a year with the top representatives of the ECU to also monitor the member states and take appropriate action when necessary. ${ }^{6}$ These new institutional arrangements represent an ECU-attempt at stricter political control of the member states without changing the membership within the ECU. It needs to be seen whether this attempt will be effective in restoring financia prudence and economic prosperity.

\section{An attempt to understand the Greek case}

A potential route to understand the interaction between the ECU and Greece rests on the following assumptions and implications.

\section{Assumptions}

A. Most European politicians consider the ECU such a precious asset that they try to avoid its collapse at almost any cost.

B. Most European politicians regard disorderly default of Greece as a strong threat to the ECU.

C. A disorderly default of Greece may trigger unpredictable reactions in capital markets which in turn may trigger strong shocks to the real economy.

\section{Implications}

1. In the game between the ECU and Greece, the (strong) ECU is a hostage of (distressed) Greece.

2. A haircut for Greece is a free lunch. This also encourages other distressed member states to insist on a haircut.

3. A generous haircut policy changes the perception of ECU-sovereign bonds from safe to high-yield bonds with strong implications for future issuance of sovereign bonds.

4. Monitoring of national politics not only by the ECU but also by investors is required for financia discipline. A coordination mechanism without capital markets does not work ("externalization hypothesis").

${ }^{6} \mathrm{The}$ ECU insisted on an austerity program of Italy. The Italian government sent a letter to the ECU in which it promised certain steps together with a time schedule for implementation. Moreover, Italy had to accept officia monitoring by the IMF, in addition to that of the ECU. 
5. The typical erratic sequence of political announcements and decisions together with frequent revisions of announcements and decisions undermines credibility of politics. This reinforces ambiguity in capital markets and weakens capital market control.

First, we explain and discuss the assumptions.

A. Most European politicians consider the ECU such a precious asset that they try to avoid its collapse at almost any cost.

European history is a history of many wars between European countries, in particular France and Germany. After the disastrous two world wars in the last century, political heads of France, Italy, Germany and the Benelux-countries agreed on the European Community for Coal and Steel in 1951. Only six years later the same countries agreed on the Treaty of Rome to establish the European Economic Community. In 1986 the European Single Market was codified Then in 1992 the European Currency Union was agreed upon in the Treaty of Maastricht. This treaty was amended in 2001 in the Treaty of Nice and finall in the Lisbon Treaty in 2007. This treaty establishes many elements of a political union even though national autonomy still plays an important role. The political success of the European Union is easily visible by looking at the rapid expansion from initially six to now 27 member states. Moreover, additional countries apply for membership. Despite the difficultie in coordinating the member states, the European Union and the ECU are perceived as a model of success. Hence, many European politicians try to avoid a collapse of both unions at almost any cost.

\section{B. Most European politicians regard disorderly default of Greece as a strong threat to the ECU.}

The Euro as the single European currency was agreed upon in the Maastricht Treaty for various political reasons, one being the strong political symbol of unionization. In addition, a single currency reduces transaction costs of international trade and services and it may foster international trade since exchange rate uncertainty is eliminated. ${ }^{7}$ But a currency union eliminates the adjustment mechanism of exchange rates and, thereby, generates other risks as documented by the current crisis. When the Greek problem was discussed by the European Council in May 2010, the officia version was that a collapse of Greece would be a collapse of the Euro. Hence to restore the credibility of the Euro, the Council argued that a collapse of Greece must be avoided. In May 2010, the Greek problem was presented as a problem of temporary illiquidity. German Chancellor Merkel told the public in May 2010 that there was no alternative to financiall supporting Greece. Otherwise there might be a breakdown of the ECU which might destroy the process towards a political union. Similarly, in October 2011, the exclusion of Greece from the ECU was never considered an alternative. The Lisbon Treaty does not contain any rules for excluding a member state.

C. A disorderly default of Greece may trigger unpredictable reactions in capital markets which in turn may trigger strong shocks to the real economy.

\footnotetext{
${ }^{7}$ However, a random exchange rate also offers real options to exporters and importers which may encourage international trade (Franke 1991)
} 


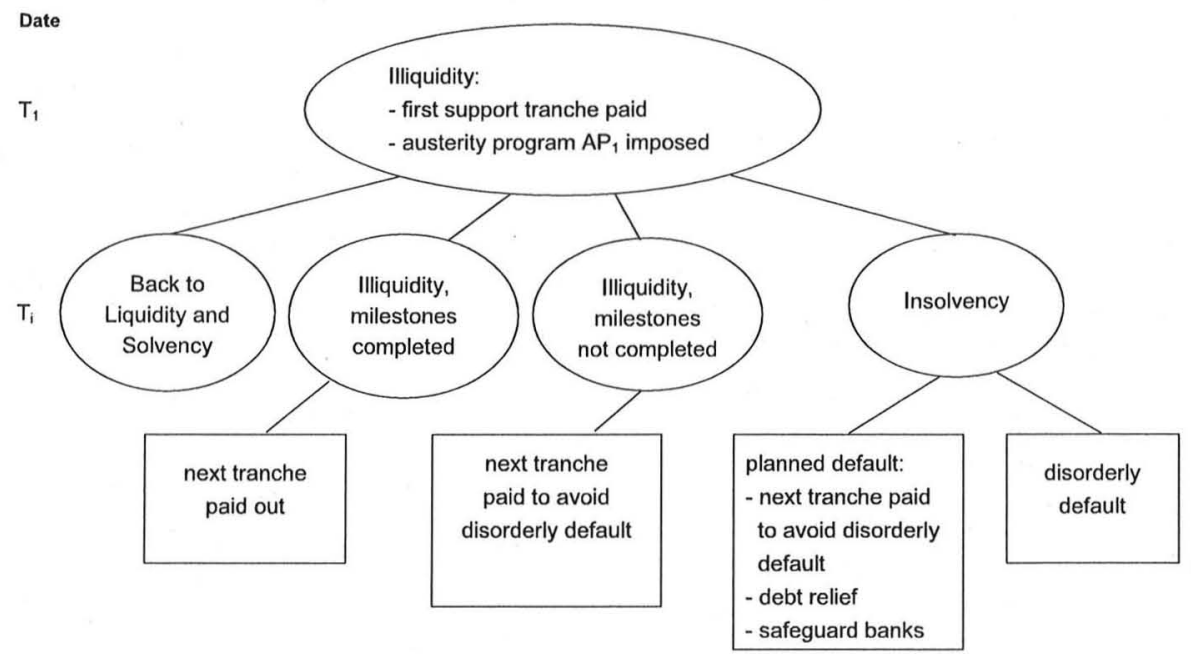

Fig. 3 Potential trajectories of an illiquid Member State in the absence of an Insolvency Charter

The heavy damages caused by the Lehman-collapse took most observers by surprise. The problem was that the collapse triggered not only losses of counterparties, but also other risk factors in an unforeseeable manner. The combination of these risk factors turned out to be disastrous for the real economy. Therefore, governments, fi nancial intermediaries, other companies and households are very much afraid of a similar event. A disorderly default of Greece might have similar effects so that there is widespread agreement to avoid such an event.

What are the implications of these assumptions?

\section{In the game between the ECU and Greece, the ECU is a hostage of Greece.}

Consider the dynamics of the game as illustrated in Fig. 3. In the firs stage of this game at date $T_{1}$, Greece is regarded as temporary illiquid. The ECU promises finan cial support against imposing a strict austerity program $\mathrm{AP}_{1}$ on Greece. To monitor the implementation of this program, the financia support is cut into tranches. The firs tranche may be paid out immediately. The following tranches can only be paid out upon the completion of milestones define in the austerity program. There are several possibilities in later stages of this game. At some date $T_{i}$, Greece may have returned to liquidity so that further financia support is not necessary (best case scenario). Or illiquidity continues (medium case scenario). Then there are two sub-scenarios. In the first milestones have been completed, so the next tranche will be paid out. In the second sub-scenario, milestones have not been completed. Then Greece will argue that it could not complete the milestones because the austerity program is too tough to be implementable in the given time span. On the other side, the ECU is able to pay out the next tranche. Thus, the ECU faces the choice of helping or not. If it does not help, then there would be a disorderly default of Greece. This would endanger the ECU (Assumption B). By Assumption A, this is not tolerable to most European politicians. Also, a disorderly default would generate unpredictable consequences in Greece and in financia markets (Assumption C) which are also intolerable. This 
eliminates the freedom of choice on the side of the ECU. Therefore, the ECU has to help. The ECU is a hostage of Greece. Ironically, it turns out that the powerful player in this bilateral game is captured by his objectives not to endanger the ECU and to avoid chaos in financia markets. This enables the distressed weak player to exploit the strong player.

This hostage-effect is similar in case the illiquidity crisis has deteriorated to an insolvency crisis (worst-case scenario). Then the ECU also faces the choice between orderly and disorderly default. According to our assumptions, a disorderly default is not tolerable. Therefore, the ECU does everything to avoid it by arranging a planned default. This involves a planned, "voluntary" debt relief with precautionary measures to safeguard banks, but also the payout of the next tranche to Greece. Without the latter, a disorderly default would still threaten financia stability. Therefore, also in this scenario the (strong) ECU is a hostage of the distressed Greece.

For illustration, consider what actually happened between Greece and the ECU. The troika is responsible for checking the completion of the milestones. Sometimes the troika complained that Greece had not completed milestones. Then Greece changed some of its policies and promised more action. In October 2011, the troika even acknowledged a negative surprise regarding the Greek economy, but nevertheless recommended the payout of the next tranche. Hence, in the end the troika always "verified the completion of the milestones so that the next tranche could be paid out. This clearly demonstrates that the ECU is a hostage of Greece.

2. A haircut for Greece is a free lunch. This also encourages other distressed member states to insist on a haircut.

At the firs stage of the game at date $T_{1}$ (Fig. 3), Greece was considered illiquid, but solvent. Financial support was granted against an austerity program $\mathrm{AP}_{1}$. If at a later stage Greece deteriorates to insolvency, markets and politics perceive the debt of Greece as too high to be repayable. Thus, Greece needs a debt relief.

This leads us to the economics of a debt relief. The standard model of a debt relief is well known from informal (= out of court) restructurings or workouts of companies in financia distress. The standard model either involves the transfer of equity claims to creditors (bail in through a debt-equity swap) or "fair" contributions of creditors and equity owners. In the firs arrangement, owners are not able or not willing to provide new equity capital. Therefore, they transfer all their equity claims to the creditors. In the second arrangement of "fair" contributions, creditors give up some of their existing debt claims and provide new money to improve their overall position. This improvement can be achieved in various ways. Equity owners provide new equity capital and/or transfer part of their ownership claims to creditors. It is essential that creditors and owners improve their positions by the informal agreement. Fresh money combined with a redistribution of equity claims among creditors and equity owners and a debt relief would be "fair" if each group preserves the market value of its position. In a Modigliani-Miller world this arrangement would be market-valueneutral. If, in addition, the company's policy were improved (because the company is restructured and agency problems which are typically reinforced in a situation of financia distress are mitigated through the informal workout), then the market values of both, the positions of creditors and of equity owners, would increase. The important lesson is that the informal workout does not lead to a free lunch for creditors or 
owners. Both groups gain in the informal workout, but not by expropriating the other group. If the owners expropriated creditors in the workout, then creditors would stop their cooperation so that the informal workout would fail.

Moreover, the free lunch would provide a strong incentive for the owners to expropriate creditors before the informal workout, for example through excessive dividends. Then, in the ensuing financia distress, they would enforce the informal workout together with the free lunch. This would terminate cooperation of creditors and, thus, debt financin of companies.

Regarding sovereign insolvency, the firs arrangement, i.e. a dropout of equity owners, is not feasible because the citizens of the insolvent country cannot be expelled. Therefore only the second arrangement is feasible. Recall that a debt relief is not discussed in the firs stage of the game, but only at a later stage. At that stage, Greece has already implemented some austerity measures which, however, have not prevented insolvency. Thus, Greece claims that it has already implemented the austerity program to the extent which is politically and economically tolerable and cannot do much more. The Greek citizens being the "owners" of Greece suffer already heavily from the austerity measures implemented so far so that they refuse additional burdens like higher taxes, lower wages and pensions, etc. Thus, they claim not to be able to give up claims in favour of the creditors. Hence, a debt relief amounts to a free lunch. ${ }^{8}$ This could only be avoided if the initial austerity program $\mathrm{AP}_{1}$ were replaced by an austerity program $\mathrm{AP}_{2}$ which imposes stronger burdens on Greek citizens to the benefi of creditors. But that is claimed to be non-tolerable.

If Greece gets a free lunch through a debt relief, then other highly distressed countries like Portugal or Ireland could also insist on a debt relief. This would be a typical domino effect. A free-lunch debt relief could also reinforce ex ante moral hazard of distressed member states. They could try to borrow more and more money in capital markets, consume it and then insist on a debt relief. This moral hazard and the ensuing debt relief would discourage private lending to sovereigns.

These arguments may explain why the ECB, in particular, strictly argued against a general debt relief. Of course, the ECB also holds large positions of Greek bonds which would be devalued in a general debt relief. How do we interpret the substitution of a general debt relief by the selective debt relief of 50 per cent on Greek government bonds held by banks and insurance companies? This "voluntary" haircut is not an outcome of a game between Greece and its creditors, but between banks and their local governments. This game is dictated in part by the financia crisis of 2007 to 2009 in which governments bailed out the banks domiciled in their countries. It appears that governments attempt to claim back some of the financia support offered to banks in the preceding years. But the moral hazard effects of a selective debt relief are similar to those of a general debt relief.

3. A generous haircut policy changes the perception of ECU-sovereign bonds from safe to high-yield bonds with strong implications for future issuance of sovereign bonds.

${ }^{8}$ Sometimes it is argued that a penalty for Greece would be to establish an external austerity commissioner with strong power in the Greek administration. The troika has already a similar role. It is questionable whether the chances to implement an austerity program are better if an external commissioner takes responsibility instead of the Greek government/parliament. 
Since Greece is the firs member state of the ECU to obtain a debt relief, the ECUstrategy towards Greece may be interpreted by investors as a model of behaviour towards other member states in distress. Thus, the ECU-behaviour in the Greek case may set a precedent for similar cases in the future. If the ECU adopts an "easy haircut" policy, then this will impair the rating of government bonds making borrowing more costly. As argued by Bindseil and Modery (2011), the perception of government bonds as safe bonds has already suffered. Credit spreads of Greece, Spain, Italy, Portugal and Ireland have gone up dramatically in the last two years. Accordingly, the big rating agencies downgraded these countries by several notches. This may have strong feedback effects. Institutional investors, including pension funds and mutual funds with statutory restrictions on the bonds in which they may invest, may have to sell off those bonds which now violate these restrictions. Banks also used to hold large positions in government bonds for liquidity management. So far, government bonds have served as primary collateral for repurchase transactions because of their strong quality. If their quality decline is perceived to be permanent, then their usefulness as collateral declines as well. The higher risk weights presumably attached to government bonds in the next Basel accord and in Solvency II also reduce the incentive for banks and insurance companies to hold government bonds. Moreover, hedging the default risk of government bonds is made difficul since credit default swaps may not pay any damage claims in case of a "selective" default. Hence finan cial intermediaries check their business model regarding government bonds. If they reduce their government bond holdings substantially, then a big creditor potential is lost. This would reinforce the transition of sovereign bonds to high-yield bonds.

Even though some Northern ECU-states like Germany and the Netherlands are considered healthy, their quality would also be endangered by a generous haircut policy because this would likely be combined with stronger financia support of the ECU for distressed member states. This support would involve transfers of the Northern ECU-states and weaken their credit rating. Hence credit spreads of these states would go up as evidenced by the last two years. Even though the fligh to quality temporarily reduces the yields to maturity of the government bonds of the strong states, the increase in their credit spreads indicates that their yields are likely to go up when markets normalize.

Moreover, nowadays the downgrade of a country has an adverse feedback effect on banks domiciled in the country because local banks are affected in various ways by the quality of its home country. The bank rating is usually no better than that of the home country. Hence, a country downgrade is likely to trigger a downgrade of local banks. This makes (forced) recapitalization of banks more difficult

All these feedback effects of a generous haircut policy can be quite dramatic as illustrated in the Greek case. Therefore the ECU needs to take these effects into consideration when definin its policy towards distressed member states. If the ECU wants to avoid these effects, it has to signal clearly that a debt relief will be a rare exception.

4. Monitoring of national politics not only by the ECU but also by investors is required for financial discipline. A coordination mechanism without capital markets does not work ("externalization hypothesis"). 
A currency union can only be sustainable if member states follow similar policies to assure their competitiveness and fisca prudence. For example, if unit labour cost strongly differs within a currency union, then countries with high cost are likely to face high unemployment. Their trade balance is also likely to show a deficit These weaknesses are likely to lower tax revenues and to raise the cost of the welfare system. Hence, a lack of international competitiveness is likely to undermine fisca prudence. The ECU has different tools to coordinate member states so as to constrain differences in competitiveness. But these tools are insufficien as will be demonstrated in the following. EU-directives are one instrument to homogenize national economic legislation. These directives defin a set of rules which have to be implemented in national legislation within a given time period. In addition, the EU-commission can issue ordinances which have to be observed in member states. Yet, implementation and enforcement of rules vary in member states. This may explain why the Greek economy is characterized by a low degree of competitiveness relative to other member states (European Commission 2010). In addition, the impact of the EU on privatization/nationalization of industrial sectors is small. As nationalized industries are often protected against competition, they tend to be economically inefficient

European legislation does not coordinate national rules for retirement, pension systems, wage and price increases. This explains why changes in purchasing power and unit labour cost varied substantially among member states over the last ten years so that competitiveness of some member states declined while it improved in other states. Moreover, member states have much freedom in designing their tax systems. Ireland, for example, still attracts foreign investors with low tax rates. Greece appears not to enforce payment of direct taxes with strong implications for the budget. One may view these "cultural" differences as desirable, but they endanger the stability of the ECU and, thus, are tolerable only to a limited extent.

Regarding fisca prudence, although there have been more than 20 defici procedures since the start of the ECU, financia sanctions have never been imposed on member states. This may not be surprising since every financ minister sitting in the ECOFIN has a dual role of being the potential victim of a defici procedure and of being the judge of his colleagues. Moreover, he has to cooperate with his colleagues on European financia issues and, thus, depends on their willingness to cooperate. Hence, a financ minister is very unlikely to be an independent monitor of fisca prudence of his colleagues. This may explain why Greece did not incur any sanctions although it violated the 3 per cent rule in each year since 2000 : Therefore, the political sanctioning mechanism of the Lisbon Treaty is ineffective.

This ineffectiveness is supported by the political process. On the one hand, politicians are strongly interested in pursuing the long-term process of unionizing Europe; on the other hand, they depend on the short-term support of parliaments and taxpayers for their rescue actions. Every rescue action indicates a weakness of the union which may be attributed to a failure of politics. Moreover, in a rescue action some member states are supported at the expense of others. This conflic of interest makes it difficul to obtain support of parliaments and taxpayers in the supporting states. Therefore politicians have an incentive to deny the existence of weaknesses. If they cannot deny it, they have an incentive to play down the weakness and the required rescue action. That makes it easier to obtain public approval for a non-beloved res- 
cue action. This misrepresentation of the situation aggravates the ineffectiveness of political monitoring.

This conclusion is supported by the development of the ECU-crisis portrayed in Sect. 3. Starting in December 2009, S\&P highlighted the financia problems of Greece. Yet, politicians did not pay much attention to the Greek defici until spring 2010 when credit spreads for Greece and some other member states went up dramatically. This generated serious doubts on the Greek ability to fund its budget and its current account deficit to refinanc its maturing debt and to fund the beginning capital flight The turbulences in the week ending on May 7, 2010, forced politicians to fin a quick solution for the crisis over the weekend. Politicians were afraid of unpredictable reactions of capital markets in case a solution was not found before Monday morning. Since it was impossible to contact private creditors of Greece over the weekend, the only available solution was to make the taxpayers of the ECU-states liable for Greece.

This episode clearly illustrates the role of politics and of capital markets in monitoring fisca discipline of ECU-states. As long as capital markets including rating agencies did not question fisca discipline, ECU-politics stayed silent. Only when liquidity of Greece appeared endangered as indicated by the soaring credit spread, ECU-politics reacted. Similarly, Ireland and Portugal got financia support from the ECU after their credit spreads had gone up dramatically. This scheme persisted also in 2011. Capital markets started to seriously question the solvency of Italy in summer 2011. The Italian government reacted by an austerity program, but mitigated this program shortly after when capital markets had calmed down. The immediate adverse reaction of capital markets then induced Italy to strengthen its austerity program.

The forceful reaction of capital markets annoys politicians because they feel strong pressure of capital markets. They are afraid that the prime role of politics is undermined by capital markets. Therefore, politicians try to mitigate or to escape from the control of capital markets. As an example, many European politicians advocate the establishment of a European rating agency claiming that the big three agencies do not correctly understand European politics and issue biased ratings. One European Commissioner even suggested a temporary prohibition of new ratings in a crisis period. Similarly, funding distressed member states by EFSF-money helps to escape capital market control because bonds issued by the EFSF are jointly guaranteed by all ECU-states and, thus, pay a fairly low interest rate independent of the quality of the supported member state. Also, ECB-purchases of government bonds in the secondary market undermine the market mechanism.

The preceding discussion clearly illustrates that ECU-politics has been unable to assure fisca discipline of the ECU-member states. In the words of Williamson (1975), the hierarchy of the ECU has failed to assure the coordination of member states required for a viable currency union. The reason is that the hierarchy is not acting through a strong management body, but through various boards and councils composed of almost equal partners with strongly divergent interests. This indicates strong "imperfections" of the hierarchy so that, in the spirit of the internalization hypothesis, part of the coordination needs to be "externalized" to capital markets. Capital markets cannot take decisions about government budgets, but they can send signals which help politicians to formulate viable strategies. The impact of capital 
market control should be stronger, the weaker the political control is. In other words, the more severe the deficiencie of ECU-politics in monitoring and in reacting to $\mathrm{f} i$ nancial distress are, the more should the ECU-handling of distressed states react to signals of capital markets. This is the essence of the "externalization hypothesis". The new project of a European Economic Government may alleviate the deficiencie of political monitoring, but it is hard to believe that it would eliminate them. If it turns out to be effective, then this would lead to a weaker role of capital markets.

"Externalization" does not question the primary role of politics. ECU-politicians have to decide about general procedures how to monitor and support distressed member states and also, from case to case, about the measures to be taken. These procedures should assign a role to capital markets as an "external" mechanism to reinforce timely political action. This should help to overcome the natural incentives of politicians to delay action on economic and fisca imbalances. Investors in government bonds act as a more objective observer of fisca prudence because they may have to bear the consequences of fisca imprudence without being involved in fisca decisions. Through credit spreads investors signal their martingale probabilities of sovereign default together with their expected loss given default. If credit spreads are soaring, then politicians should act upon this signal.

The externalization hypothesis does not claim that monitoring of capital markets works without deficiencies An open question is why rating agencies did not start a serious discussion about Greece until December 2009. One possible answer might be that investors and rating agencies believed in the umbrella theory, i.e. they did not believe in the no-bailout clause. Doubts about this theory might have been triggered by the financia crisis of 2007 to 2009 which clearly raised the public debt of most ECU-countries and their credit spreads, too. Hence, the ability of the ECU to provide sufficien financia support to distressed member states might have been questioned. This may explain the late change in ratings.

Another weakness in the monitoring of capital markets is the bias in observed credit spreads for sovereigns. These are likely to be downward biased because of the umbrella theory or other support granted by the ECU and because of the interventions of the ECB in secondary sovereign bond markets. Observed credit spreads are "support credit spreads", in contrast to "stand alone credit spreads". This distinction is an analogy to "support rating" and "stand alone rating" issued by the rating agencies for banks which might be supported by the government in case of financia distress. This distinction has implications for the monitoring of capital markets. The stronger the ECU-support, the weaker is the differentiation of credit spreads among member states. Moreover, the adjustment of credit spreads to new information on the financia situation of member states will be of a smaller size. This may lead to wrong inferences and, thus, weaken the monitoring role of capital markets.

Another criticism of capital markets is the claim that in a crisis credit spreads and bond yields of distressed countries tend to be upward biased. This upward bias may be explained by strong ambiguity of future prospects which is likely to depress bond prices, by investors hoarding money in safe heavens and by financia intermediaries being stressed by negative prospects so that their ability to take sovereign risks is reduced.

5. The typical erratic sequence of political announcements and decisions together with frequent revisions of announcements and decisions undermines credibility of 
politics. This reinforces ambiguity in capital markets and weakens capital market control.

As illustrated in Sect. 3, European politics towards Greece has moved from a "pure" liquidity support combined with an austerity program to a "selective" default. Initially politicians denied any haircut. Then they said that a haircut of 21 per cent would suffice but a few weeks later they imposed a haircut of 50 per cent. Similarly, in May 2010 a support package of 109 bio $€$ was announced to be sufficient One year later, an additional package of 100 bio $€$ was claimed to be necessary. Most of the projections and rescue actions announced by politics rather quickly turned out to be overly optimistic and needed to be revised. This undermined the credibility of politics. As argued before, the rationale for this erratic sequence of steps taken so far by European politics can be explained by the desire to play down the problems and the required rescue actions so as to get the support of parliaments and citizens, at least in the short run.

There is a cost to this policy. Not only has credibility of politics been severely impaired but it has also become very difficul for investors to predict their default risk. The associated ambiguity about EU-politics also provides more room for influentia rumours and invites a multitude of suggestions as to how the EU should proceed. This reinforces ambiguity.

If investors base their decisions on a worst-case scenario as suggested by the model of Gilboa and Schmeidler (1989), markets will break down. More generally, ambiguity about EU-politics raises credit spreads for sovereigns and depresses prices of government bonds in a manner which makes it difficul to analyse the content inherent in these signals. The signal content is reduced. Even worse, there are likely multiple equilibriums in the game between lenders and distressed states rendering the interpretation of market signals more doubtful (Ghosal and Miller 2003).

\section{On a European Insolvency Charter}

I argue that the lack of a credible EU-strategy is explained in part by a lack of a European Insolvency Charter. A Charter would restrict discretion of the ECU-politics by providing guidelines for restructuring distressed member states. By constraining "random walks of politics" a Charter should also help to restore credibility of politics. A Charter would make it easier for investors to forecast EU-politics and, hence, default probabilities and losses given default. This would allow investors to send more credible market signals. To achieve these objectives, a European Insolvency Charter should address not only distressed member states, but, equally important, EU-politics. Ghosal and Miller (2003) argue in general that "in the absence of bankruptcy style procedures, there will almost always be excessive disorderly default in sovereign bond markets".

It makes a big difference for the design of an insolvency charter for sovereigns whether it addresses an "independent" distressed state or a state which is a member of a currency union. In the firs case, a sovereign with credit relations mainly to private lenders, such as Argentina in 2001, needs to be reorganized. The distress primarily affects private lenders and much less other sovereigns. In the case of a currency union 
the distress is likely to produce major externalities to other member states of the currency union, partly because other member states including the joint central bank are lenders. But, what is more important, the close cooperation between the member states in a currency union is endangered. The member states in a currency union need to take joint action if a member state turns insolvent. Due to the strong ties between member states, reorganization is a process run jointly by the insolvent member state and the other member states. Hence, a European Insolvency Charter would need to address not only the reorganization of the insolvent state but equally the rules for interaction with the other member states.

As a start, it is useful to understand why there is no institutional arrangement for a procedure in the case of illiquidity/insolvency of a member state. First, European politicians did not want to acknowledge any serious risks of the currency union hoping for a self-fulfillin prophecy of a stable union. Second, another obstacle is the lack of a fina vision of the European Union. The political process of unifying Europe has started a few decades ago, subject to strong cultural differences between member states. These so far prohibit a European constitution with a strong European government and parliament, a prerequisite for a stable currency union. A European Insolvency Charter can hardly be finalize without a fina vision of the union (Di Fabio 2011). For example, the Charter would depend on the mutual support which member states are ready to provide for each other. If a union is a collection of nations, then this support is likely to be smaller than in a union of states which share a joint "union identity". As long as the convergence from strong cultural heterogeneity to some "union identity" has not been achieved, a European Insolvency Charter cannot be finalized Third, there exist proposals for a Sovereign Debt Restructuring Mechanism (SDRM); see, for example, Krueger (2002) and Bolton (2003) which, however, have never been enacted in international agreements. An SDRM would serve as an insolvency charter for "independent" sovereigns. It should establish rules for (a) restructuring the sovereign's debt, (b) providing fresh money for the sovereign, and (c) restructuring the sovereign's economy. It should also reduce uncertainty about the rights of the creditors and their coordination in debt restructuring, for example through collective action clauses.

Although there are strong arguments for an SDRM, it has not yet been enacted due to various unresolved issues. To mention a few, (1) there is the difficult in definin implementable criteria for illiquidity and insolvency of a state. If a state is temporarily illiquid, it may still be solvent. An insolvent state should be permanently illiquid, given no outside rescue action. But there is no simple accounting indicating illiquidity or insolvency of a state. What matters is the long-term cash $\mathrm{fl} \mathrm{w}$ generating capacity of the state relative to its debt. This capacity depends on many factors which are not easy to predict. A frequently used insolvency indicator is the ratio of public debt over the primary budget surplus. But this simple indicator does not address the risk factors behind the financia distress. The IMF and the World Bank have developed criteria to estimate debt sustainability of low-income countries (IMF 2011). They evaluate countries according to policy weakness and to protracted breach of certain thresholds. This work might help to distinguish between illiquidity and insolvency. (2) Who should be entitled to fil for an insolvency procedure? The distressed country, its creditors and, perhaps, some international organization might have the 
privilege to file But potential moral hazard problems need to be considered. Politicians in the distressed country may have an interest to delay an insolvency procedure as found by Reinhart and Rogoff (2011). But they may also fil for insolvency to obtain a large debt relief which is not justifie by its economic prospects. On the other hand, a creditor being in a weak position relative to other creditors might threaten the country to fil for an insolvency procedure to improve his position at the expense of other creditors or the distressed country. In case of the ECU, the Council might have the privilege to fil for insolvency of a distressed member state. But since the other member states of the ECU are involved as counterparties in an insolvency procedure, they also may be guided by moral hazard. Their situation could be similar to that of the IMF in sovereign debt restructuring (Bolton 2003). As a correction mechanism, a European court might decide whether an insolvency procedure should be started or not. But as long as there are no reliable criteria for illiquidity and insolvency, it will be difficul to avoid moral hazard on the side of the country and of European institutions. These are some of the problems in designing a SDRM and a European Insolvency Charter. Yet, it would be useful to develop such a charter step by step to curb the problems illustrated in the Greek case.

The need for a European Insolvency Charter has been acknowledged on various occasions. The Council discussed such a charter in October 2010. But many member states oppose such a charter perhaps because they are afraid of being put under pressure by it. Fuest et al. (2010) proposed a charter as did the scientifi advisory board of the German Ministry for Economics and Technology (Wissenschaftlicher Beirat 2011). Sinn and Carstensen (2010) suggest a 3-step procedure for illiquid member states. At the firs stage, creditors and the distressed state agree voluntarily on a haircut. If that does not work, then at the second stage the ECU and the IMF assist to enforce a haircut. For this haircut a limit exists to reduce uncertainty for investors. At the third stage, the ECU can help the distressed country to issue new bonds with a partial ECU-guarantee provided that the country enforces the milestones of the reorganization program. Although these proposals are helpful to motivate the design and enactment of a European Insolvency Charter, a lot of work is needed for a detailed charter which credibly eliminates the danger of the ECU to become a hostage of insolvent member states, the free lunch of a haircut and the associated moral hazard problems of distressed countries. The charter would also have to discourage moral hazard of the ECU.

Recent ECU-politics try to bypass an insolvency charter by a pre-planned procedure which resembles an informal workout. Figure 4 portrays three different types of default for a member state of the ECU. The firs type is the "disorderly default". It is characterized by the absence of an institutional insolvency arrangement and of an "ad hoc planned insolvency" procedure. Thus, the distressed country would stop its debt servicing without prior notice. It would be motivated to default strategically so as to maximize its default benefi (Herman 2011). This might trigger unpredictable reactions in capital markets, due to unpredictability of financia support of the ECU and the ensuing unpredictability of the loss given default of financia intermediaries. In addition, domino effects of other distressed member states might create a systemic risk for the ECU which is regarded as non-tolerable by most politicians. The potential chaos in financia markets would force EU-politics to react very quickly to calm 


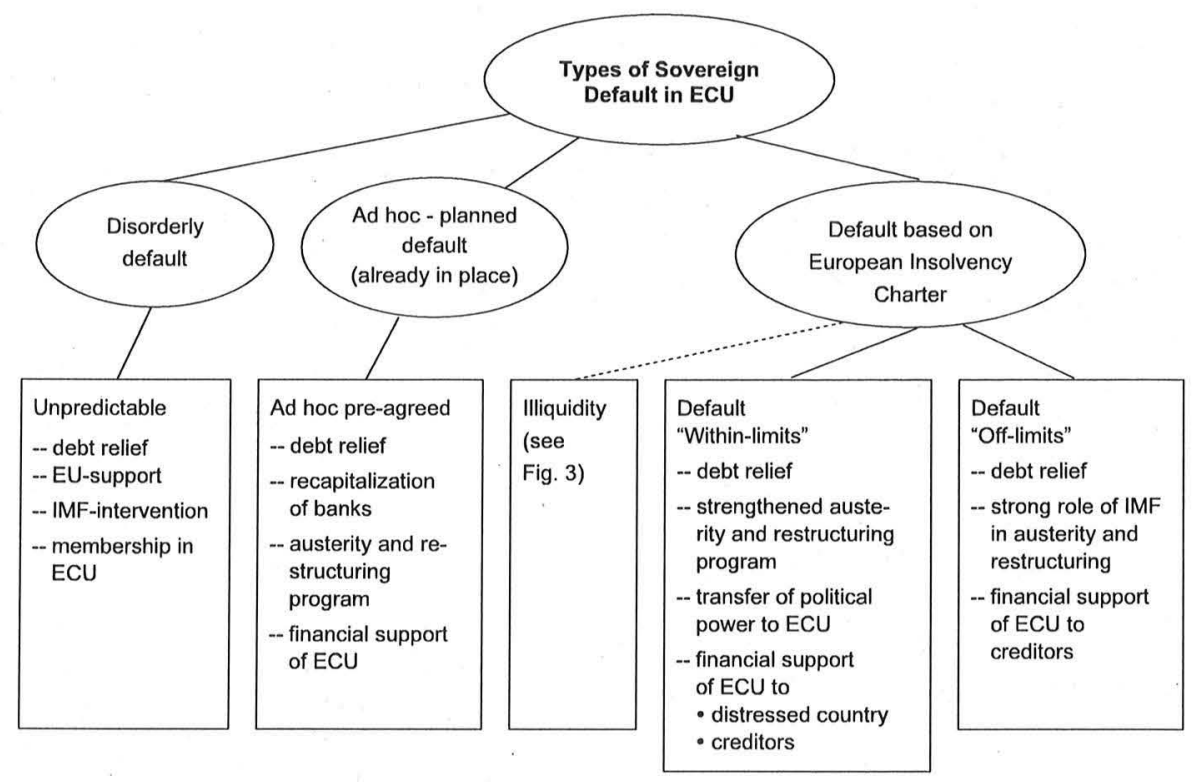

Fig. 4 Different types of default of ECU-Member States

down markets. This would preclude an orderly arrangement with creditors and the distressed member state. As a consequence, the taxpayers of other states would have to step in bailing out the distressed state and its creditors. This is clearly inefficien and, therefore, undesirable.

The second type of default is "ad hoc planned default". This is an ad hoc arrangement to avoid unpredictable capital market reactions. The ECU, the distressed member state and financia intermediaries pre-agree on burden sharing so that losses of financia intermediaries become predictable. Moreover, their required recapitalization is assured by their home countries, but only as a backup if private recapitalization should fail. This default type has been used in the Greek case and it was successful in the sense that a balance between a debt relief of financia intermediaries and financia support of the ECU was struck and capital markets were stabilized, at least temporarily. Another advantage of the "ad hoc planned default" is that it offers much fl xibility in a situation for which little experience exists. This is the good news. But there is also bad news as illustrated by the Greek case. Politics acted mostly in an ad hoc manner and lost much credibility due to "muddling through". Moreover, the ECU remained a hostage of the distressed member state and the debt relief was a free lunch. This reinforces moral hazard of distressed countries. The incentives for distressed states to restructure their economies so as to restore international competitiveness and fisca prudence are likely to be weakened. Also the incentives to implement the austerity program imposed by the ECU will be impaired. Therefore, "ad hoc planned default" is not a viable default type.

The third type of default is "chartered insolvency". First, the Insolvency Charter should provide criteria to distinguish between illiquidity and insolvency. Since the distinction between both is difficult the Charter might defin some criteria which 
serve as a starting point for the "illiquidity conjecture" resp. the "insolvency conjecture". In addition, procedures to overrule these conjectures need to be define in such a way that overruling is made difficult Illiquidity would not be considered a type of default and be handled as illustrated in Fig. 3. Second, the Insolvency Charter should put a stay on debt collection as should an SDRM. As argued by Bolton (2003), an SDRM should enforce a stay on debt collection efforts by single creditors or groups of creditors to avoid a run on public assets and on assets of state-owned companies. The SDRM should facilitate joint action of creditors by collective action clauses so that minorities of creditors can be forced to join an agreement on debt relief and reorganization. It might even include cross default rules to homogenize interests of different creditor groups. At the same time, priority rules among creditors need to be observed to assure ongoing trade financing and to protect creditors who provide fresh money once an insolvency procedure has been started.

Third, I propose two insolvency settings, one called "Within-limits", the other one called "Off-limits". Given an insolvency "Within-limits", creditors would agree to a debt relief and the ECU would provide sufficien financia support to the distressed member state to avoid a general default. A general default would cut back all claims against the state by a certain percentage. That would be undesirable because it would endanger the working of the government and of the public infrastructure. Given an insolvency "Off-limits", the ECU would provide less or no financia support. This would impose a higher burden on creditors and on the insolvent state. The Charter should set rules definin these limits.

The distinction between "Within-limits" and "Off-limits" has two immediate effects. (1) The ECU is not forced to provide financia support once the member state has crossed the limits. The ECU might still supply some fresh money to maintain some subsistence level of private and state activities. But the ECU can credibly threaten the insolvent member state to provide less money than required for maintaining liquidity, should the state cross the limits. Thus, the ECU could avoid becoming a hostage. (2) Also, given "Off-limits", the cutback of financia support removes the free-lunch problem in a sequential game. The unavoidable debt relief goes together with a cutback of financia support which is equivalent to a new burden on the member state. This burden may not be sufficien to balance the debt relief, but it clearly indicates that the debt relief comes at a cost for the state and its citizens.

The free-lunch problem is more difficul to counteract, given "Within-limits". The debt relief should come at a cost to the distressed state in a sequential game. This might be a political cost, for example, in terms of a temporary transfer of political power from the distressed state to the ECU. Or it might be a financia cost in terms of an intensifie austerity program or a combination of both. Or, as has been done sometimes in the past, the creditors exchange their claims for new claims which have a smaller par value, with a call option attached. This option links future payments to the recovery of the member state so that creditors get back more money when the economy of the member state recovers faster. Thus, it reduces the free lunch. In any case, the cost should be felt by the citizens of the distressed state.

One may view a Charter which distinguishes between "Within-limits" and "Offlimits" as a rule of conditional divorce. The penalties in case of divorce should discourage member states from crossing limits. Divorce may provide a stronger role for the IMF as in restructurings of independent countries. 
At the same time, the Charter should provide some protection to creditors so as to discourage unpredictable reactions of capital markets in case of insolvency (see also Sinn and Carstensen 2010). This could be achieved by a First or Second Loss Position in sovereign bonds taken by the ECU. Such an arrangement is likely to be implemented using the EFSF as a vehicle. It is also an important signal to investors because it indicates future commitment of the ECU. A First or Second Loss Position of $x$ per cent would constrain the loss given default of private investors to $(100-x)$ per cent. Investors anticipate this and gauge their risk taking to this loss given default and, thereby, stabilize their own solvency. But there should still be a substantial maximal loss given default. This would motivate investors to charge carefully derived interest rates for sovereign bonds and credit spreads for credit default swaps. That should help to give economic content to these signals and thereby enforce the role of capital markets in monitoring member states.

As argued before, a European Insolvency Charter is more complicated than an SDRM because it also needs to address the close ties between the ECU and its member states. It should restrict discretion of ECU-politics to make ECU-politics more predictable and, thereby, more credible.

A general question is how detailed the rules of such a charter can and should be. There is always the conflic between $\mathrm{fl}$ xibility and rule guidance. Since financia distress of a member state can take various forms, there are no simple numerical defini tions. And various risk factors may lead to financia distress. An appropriate political management has to take the interplay between these risk factors into account. Some discretion is needed to apply these concepts in a sensible manner, as is true of most laws. This is particularly important in an early phase of the European unionization process. Due to the uncertainties of the process of European unionization, a European Insolvency Charter initially needs to leave many issues open which may be regulated once the details of the "final union become visible. The rules of the Charter should be revised and strengthened over time. The key is to defin the concepts for handling distressed member states in such a way that the basic concepts are clearly specifie but there is enough room for discretion in implementing them.

As a caveat, politicians might ignore the Insolvency Charter and choose their own way in handling distressed member states. Some member states might insist on policies with hostages and free lunches or they might prefer the ECB printing money to "solve" the problems. Such policies will be unattractive only if several member states refuse to support them so that these policies are not an easy solution. Then an existing Insolvency Charter should open a pre-organized procedure to solve problems with fewer conflicts Thus, a well designed insolvency procedure could turn out to be the most effective political procedure. Powerful European institutions should enforce the Charter as well. A European Supreme Court might serve this function.

\section{Conclusion}

This paper argues that due to a lack of rules how to handle distressed member states the ECU faces many problems which endanger its existence. First, the ECU is a hostage of distressed member states because a disorderly default would endanger the 
process of unionization. This forces the ECU to provide financia support combined with an austerity program. If the distressed state does not return to financia health, but deteriorates into insolvency, then creditors need to grant a debt relief. This relief represents a free lunch because the failure of the state to complete the milestones indicates that the state is not able or not willing to enforce the austerity program. Hence, the debt relief is granted without any sacrific in return. A debt relief being a free lunch may easily enforce moral hazard of other member states.

European politics has lost much credibility because in each step of the crisis politics played down the problems and the required rescue actions to obtain public support. Shortly afterwards, the announcements had to be revised, mostly to the negative side. This irritated investors. Moreover, political monitoring by the ECU turned out to be ineffective. The sovereign crisis in the ECU started to be seriously discussed only after rating agencies and capital markets alerted the public.

Clearly, part of the observed problems can be explained by the novelty of the situation. Even though history teaches us some lessons about currency unions, the process of European unionization has many novel features whose developments are hard to predict. That makes the political game difficul and is likely to lead to a cumbersome trial-and-error process. Part of the observed problems could be avoided by an appropriate institutional framework for handling distressed member states. Such a framework should defin rules so that financia support of the ECU is granted as long as the distressed member state does not cross certain fisca and economic limits. This should save the ECU from becoming a hostage. Moreover, it should remove the free lunch of a debt relief in the "Off-limits" setting. In the "Within-limits" setting, a debt relief should also be granted only against some cost to the citizens of the distressed state. That should mitigate moral hazard.

The rules of the cooperation between politics and private creditors should be define by politics. These rules should assign a monitoring role to capital markets to complement the monitoring by European politics and, thereby, mitigate its weaknesses. Politicians should take the capital market signals into consideration in their management of distressed states. The weaker the political management is, the more important should be the role assigned to capital markets. This is the essence of the "externalization hypothesis".

Monitoring by capital markets can only be useful if European politics provide reliable information to investors. Predictability of politics should be improved by enacting a European Insolvency Charter. The Charter should constrain losses of creditors in sovereign defaults so that losses will be easier to predict and creditors can take precautionary measures to safeguard their own solvency. It will be a major task to enact a European Insolvency Charter given the strong conflict of interest between the member states.

Acknowledgements I am indebted to Manuel Ammann, the editor, Matthias Draheim, Angela Franke, Moritz Heimes and Steffen Seemann for very helpful comments.

\section{References}

Bindseil, U., Modery, W: Ansteckungsgefahren im Eurogebiet und die Rettungsmaßnahmen des Frühling 2010. Perspekt. Wirtsch. 12, 2115-2241 (2011) 
Bolton, P.: Toward a statutory approach to sovereign debt restructuring: Lessons from corporate bankruptcy practice around the world. IMF Staff Papers, vol. 50, Special Issue (2003)

Di Fabio, U.: Welche Legitimationsgrundlagen erfordert eine europäische Stabilitätskultur. In Schuldenkrise und Governance der Europäischen Union, vol. 51, pp. 47-55. Walter-RaymondStiftung, Berlin (2011)

European Commission: The economic adjustment programme for Greece. European Economy. Occasional Papers 61. Brussels. Internet only (2010)

Franke, G.: Exchange rate volatility and international trading strategy. J. Int. Money Financ. 10, 292-307 (1991)

Fuest, C., Franz, W., Hellwig, M., Sinn, H.: Zehn Regeln zur Rettung des Euro. Frankfurter Allgemeine Zeitung, Nr. 138, 18. Juni 2010, p. 10 (2010)

Ghosal, S., Miller, M.: Co-ordination failure, moral hazard and sovereign bankruptcy procedures. Econ. J. 113, 276-304 (2003)

Gilboa, I., Schmeidler, D.: Maxmin expected utility with non-unique prior. J. Math. Econ. 18, 141-153 (1989)

Herman, B.: How to resolve sovereign debt crises in the twenty-firs century. Initiative for Policy Dialogue Working Paper Series, June 2011

International Monetary Fund: The Joint World Bank-IMF debt sustainability framework for low-income countries. Factsheet August (2011)

Krueger, A.: A New Approach to Sovereign Debt Restructuring. International Monetary Fund, Washington (2002)

Mundell, R.A.: A theory of optimum currency areas. Am. Econ. Rev. 51, 657-665 (1961)

Reinhart, C., Rogoff, K.: From financia crash to debt crisis. Am. Econ. Rev. 101, 1676-1706 (2011)

Sinn, H., Carstensen, K.: Ein Krisenmechanismus für die Eurozone. Ifo-Schnelldienst, Sonderausgabe November (2010)

Williamson, O.E.: Markets and Hierarchies: Analysis and Antitrust Implications. Free Press, New York; Collier Macmillan, London (1975)

Williamson, O.E.: The Economic Institutions of Capitalism. Free Press, New York (1985)

Wissenschaftlicher Beirat des Bundesministeriums für Wirtschaft und Technologie: Überschuldung und Staatsinsolvenz in der Europäischen Union. Gutachten 01/11 (2011)

Günter Franke is a full professor of International Finance at the University of Konstanz. He was the head of the "Center of Finance and Econometrics" and of the research group "Price-, Liquidity- and Default Risks: Management and Distribution". His research interests include capital markets, risk management and international finance

He was President of the European Finance Association and of the German Finance Association and coordinated the financ activities of the European Institute for Advanced Studies in Management in Brussels for more than 10 years. He serves on several Editorial Boards and is a member of the Berlin-Brandenburg Academy of Science. 